\title{
Karakteristik makanan pendamping balita yang disubstitusi dengan tepung ikan patin dan labu kuning
}

\author{
Etika Ratna Noer $^{1 *}$, Ninik Rustanti ${ }^{1}$, Leiyla Elvizahro ${ }^{2}$
}

\begin{abstract}
Background: When breast milk is no longer enough to meet the nutritional needs of the infant, complementary foods should be added. Complementary feeding should be start giving from 6 months onwards. The period from 6-months of age is a very vulnerable period. It is the time when malnutrition starts in many infants. One form of complementary feeding which are hygienic, and ready to serve is an instant baby food. Utilization of local food such as catfish (Pangasius sp) and pumpkin (Cucurbita moschata) as a source of protein and beta-carotene may increase the nutrient content of complementary feeding.

Objective: This study was designed to analyze the difference of nutrients content, bulk density, and acceptability among the percentage varieties of catfish and pumpkin flour substitution on instant baby porridge.

Methods: An experimental study with a single factor completely randomized design. The experiment carried out by combining the percentage of catfish and pumpkin flour substitution in to 4 formulas. The nutrients content that were analyzed are levels of protein, betacarotene, fat, and carbohydrate. Statistical analysis of the nutrients content, bulk density, and acceptability using One Way ANOVA test CI 95\% followed by Tukey posthoc test.

Results: Instant baby food recommended is the substitution of catfish $20 \%$ and $15 \%$ pumpkin. Servings (25 g) instant baby food to meet the $34 \%$ and $102 \%$ of protein adequacy adequacy of vitamin A.

Conclusion: Instant baby porridge substituted with catfish and pumpkin flour are high in protein and vitamin A, appropriate to the bulk density, and acceptable.
\end{abstract}

Keywords: complementary feeding, catfish flour, pumpkin flour, protein, Vitamin A

\begin{abstract}
ABSTRAK
Latar belakang : Kebutuhan energi bayi usia enam bulan meningkat sebesar 24-30\% dibandingkan dengan kebutuhan saat usia 3-5 bulan. Kebutuhan gizi mutlak dipenuhi agar pertumbuhan bayi tidak terhenti atau melambat. Makanan Pendamping ASI (MP-ASI) penting diberikan pada bayi enam bulan keatas untuk memenuhi kebutuhan zat gizi yang meningkat. Salah satu bentuk MP-ASI yang higienis, praktis disajikan, dan dikenal masyarakat adalah bubur bayi instan. Pemanfaatan bahan pangan lokal seperti ikan patin (Pangasius sp) dan labu kuning (Cucurbita moschata) sebagai sumber protein dan betakaroten dapat meningkatkan kandungan gizi MP-ASI.

Tujuan : Penelitian ini bertujuan untuk menganalisis perbedaan kandungan zat gizi, sifat fisik, dan daya terima MP-ASI bubur bayi instan dengan variasi persentase substitusi tepung ikan patin dan tepung labu kuning.

Metode : Penelitian eksperimental dengan rancangan acak lengkap satu faktor. Eksperimen dilakukan dengan mengkombinasikan persentase substitusi tepung ikan patin dan tepung labu kuning sehingga diperoleh empat formula. Pembuatan bubur bayi instan dilakukan dengan metode dry mixing. Kandungan zat gizi yang dianalisis antara lain kadar protein, betakaroten, lemak, dan karbohidrat. Pengujian daya terima dilakukan dengan uji hedonik oleh 20 panelis agak terlatih. Analisis statistik menggunakan uji One Way ANOVA CI 95\% dilanjutkan dengan posthoc test Tukey.

Hasil : Bubur bayi instan yang direkomendasikan untuk dikonsumsi adalah formula D yaitu substitusi ikan patin $20 \%$ dan labu kuning 15\%. Takaran saji (25 g) bubur bayi instan dapat memenuhi 34\% kecukupan protein dan 102\% kecukupan vitamin A.

Simpulan : Bubur bayi instan dengan substitusi tepung ikan patin dan tepung labu kuning telah memenuhi persyaratan kandungan gizi, memiliki densitas kamba dan daya terima yang sesuai.
\end{abstract}

Kata kunci : MP-ASI, tepung ikan patin, tepung labu kuning, protein, betakaroten

\section{PENDAHULUAN}

Pemberian makanan padat gizi dan aman pada bayi sebagai Makanan Pendamping ASI (MP-ASI)

\begin{tabular}{l}
\hline Jurusan Gizi, Fakultas Kedokteran, Universitas \\
Diponegoro, Indonesia. \\
2 Instalasi Gizi, Rumah Sakit Pusat Paru, Kota Salatiga, \\
Indonesia \\
${ }^{*}$ Korespondensi Email : etikaratna@fk.undip.ac.id
\end{tabular}

sebaiknya diberikan mulai usia enam bulan. Bayi memerlukan tambahan energi sebesar 24-30\% karena kandungan gizi ASI sudah tidak mencukupi. ${ }^{16,17}$ Kebutuhan gizi mutlak dipenuhi agar pertumbuhan bayi tidak terhenti atau melambat.

Komponen zat gizi yang penting pada masa bayi diantaranya protein dan vitamin A. Protein untuk bayi berperan dalam pertumbuhan dan pemeliharaan sel, sedangkan vitamin A berperan dalam fungsi sistem 
imun, melindungi integritas sel-sel epitel lapisan kulit, permukaan mata, bagian dalam mulut, serta saluran pencernaan dan pernafasan. ${ }^{15,16}$ Pembuatan MP-ASI bubur bayi instan utamanya harus memenuhi kebutuhan gizi bayi. Hal ini telah diatur oleh pemerintah, antara lain kandungan energi minimal $400 \mathrm{Kkal}$, kandungan protein sebesar 15-22 g, dan vitamin A sebesar 250-350 $\mu \mathrm{g}$ dalam $100 \mathrm{~g}$ bahan. ${ }^{12}$ Pada umumnya bahan penyusun MP-ASI bubur bayi instan berasal dari campuran tepung beras, susu skim, gula halus, dan minyak nabati. ${ }^{2,20}$ Untuk meningkatkan kandungan gizi, bahan-bahan tersebut dapat disubstitusi dengan bahan pangan lokal sumber protein dan vitamin A.

Salah satu bahan pangan lokal sumber protein yang dapat dimanfaatkan sebagai bahan MP-ASI adalah ikan patin (Pangasius spp). Ikan patin merupakan ikan air tawar yang mudah dijumpai dan mempunyai kandungan protein sebesar $68,6 \% .^{10}$ Salah satu bentuk pengolahan ikan patin yang sesuai untuk MPASI adalah penepungan. Dalam $100 \mathrm{~g}$ tepung ikan terkandung 60-75 g protein, sementara kandungan protein dalam $100 \mathrm{~g}$ susu skim hanya sebesar 30 gram. ${ }^{2,13}$ Bahan pangan yang kaya akan vitamin A juga perlu digunakan untuk memenuhi persyaratan kandungan vitamin A pada MP-ASI. Labu kuning (Cucurbita moschata) merupakan salah satu bahan pangan lokal yang mengandung betakaroten cukup tinggi yaitu sebesar $1.569 \mu \mathrm{g} / 100 \mathrm{~g} .{ }^{14}$ Labu kuning dapat diolah menjadi tepung sehingga dapat digunakan sebagai bahan MP-ASI. Selain itu, protein yang terkandung dalam tepung labu kuning memiliki daya cerna sebesar $99 \%$ sehingga sesuai untuk dikonsumsi bayi. ${ }^{9}$

Berdasarkan latar belakang tersebut maka dilakukan penelitian mengenai kandungan zat gizi, densitas kamba, mutu mikrobiologi dan daya terima MP-ASI bubur bayi instan dengan substitusi tepung ikan patin dan tepung labu kuning untuk menghasilkan bubur bayi instan yang tinggi protein dan vitamin $\mathrm{A}$.

\section{METODE DAN BAHAN}

Penelitian ini merupakan penelitian eksperimental dengan rancangan acak lengkap satu faktor yaitu substitusi tepung ikan patin (10\% dan 15\% dari bahan total) dan tepung labu kuning (25\% dan $20 \%$ dari bahan total). Substitusi tepung ikan patin (Ip) menggantikan susu skim dan substitusi tepung labu kuning (Lk) menggantikan tepung beras. Komposisi awal bubur bayi instan sebelum disubstitusi yaitu $35 \%$ tepung beras, $50 \%$ susu skim, 10\% minyak nabati, dan 5\% gula halus. Formulasi yang disusun ada 4 formula, yaitu formula A terdiri tepung Ip 15\% dan $\mathrm{Lk} 10 \%$, formula B terdiri tepung Ip 15\% dan Lk
$15 \%$, formula C terdiri tepung Ip 20\% dan Lk 10\%, dan formula D terdiri tepung Ip 20\% dan Lk $15 \%$. Setiap perlakuan dilakukan 3 kali pengulangan dan pengukuran daya terima dilakukan sebanyak 1 kali.

Pembuatan bubur bayi instan dengan substitusi tepung Ip dan tepung Lk dilakukan dengan metode dry mixing. Pengolahan pati pada tepung beras menjadi bahan yang siap pakai dilakukan dengan proses gelatinisasi. Bubur tersebut kemudian dikeringkan, digiling, dan diayak dengan ayakan 60 mesh. Pengeringan tepung beras tergelatinisasi, tepung ikan patin, dan tepung labu kuning dilakukan dengan cabinet dryer pada suhu $\pm 50^{\circ} \mathrm{C}$ selama \pm 12 jam.

Kandungan zat gizi dianalisis dengan metode Kjeldahl dan soxhlet. Kadar air dengan metode oven, kadar serat kasar dengan metode gravimetri, dan kadar abu dengan metode drying ash. Kadar betakaroten dianalisis dengan menggunakan metode spektrofotometri.

Penilaian daya terima warna, aroma, tekstur, dan rasa menggunakan uji hedonik Penilaian daya terima dilakukan pada 20 panelis agak terlatih. Pengaruh variasi persentase substitusi tepung ikan patin dan tepung labu kuning terhadap kandungan zat gizi, densitas kamba, mutu mikrobiologi dan daya terima MP-ASI bubur bayi instan diuji dengan one way Anova dengan derajat kepercayaan $95 \%$ yang dilanjutkan dengan posthoc test Tukey untuk mengetahui beda nyata antar perlakuan.

\section{HASIL}

\section{Sifat Fisik MP ASI Bubur Bayi Instan}

\section{Densitas Kamba}

Pengukuran densitas kamba atau bulk density penting untuk melihat kepadatan zat gizi per satuan luas tertentu serta kaitannya dengan pengemasan dan penyimpanan (Hadiningsih, 2004; Amirullah 2008). Hasil analisis densitas kamba disajikan pada Tabel 1.

\section{Daya Terima}

Bubur bayi instan dengan substitusi tepung Ip dan Lk yang dihasilkan berupa bubuk halus berwarna kuning dan siap konsumsi setelah diseduh dengan air panas $\pm 60^{\circ} \mathrm{C}$ dengan perbandingan $1: 1$. Formulasi bubur bayi instan menghasilkan warna kuning cerah yang dapat diterima panelis dengan tingkat kesukaan agak suka. Aroma bubur bayi instan yang dihasilkan sebagian besar diterima panelis dengan tingkat kesukaan netral. Keduanya merupakan bubur bayi instan dengan persentase substitusi tepung Ip dan tepung Lk yang paling tinggi. Tekstur bubur bayi instan hanya formula tepung Ip dan Lk (10\% dan 
20\%) yang dapat diterima panelis dengan tingkat kesukaan netral, sisanya diterima agak suka. Demikian juga dengan rasa bubur bayi instan, semua formula dapat diterima panelis dengan tingkat kesukaan netral.

Tabel 1. Hasil Analisis Densitas Kamba MP-ASI Bubur Bayi Instan

\begin{tabular}{cc}
\hline Formula & Densitas Kamba $(\mathrm{g} / \mathrm{ml})$ \\
\hline A & $0,47 \pm 0,02$ \\
B & $0,46 \pm 0,02$ \\
C & $0,48 \pm 0,02$ \\
D & $0,48 \pm 0,01$ \\
\hline
\end{tabular}

\section{Sifat Kimia MP ASI Bubur bayi instan}

\section{Kadar Air}

Kadar air bubur bayi instan dengan substitusi tepung Ip dan Lb berkisar antara 5,36-5,81\%. Kadar air pada semua formula masih lebih tinggi dibandingkan persyaratan, yaitu $4 \mathrm{~g} / 100 \mathrm{~g}$ MP-ASI.

\section{Kadar Abu}

Bubur bayi instan dengan substitusi tepung Ip dan Lk mengandung abu 2,76-3,30\%. Dalam SNI 017111.4-2005, kadar abu disyaratkan tidak lebih dari 3,5 g per 100 gram produk MP-ASI. Semua formula yang dihasilkan masih memenuhi persyaratan tersebut.

\section{Kadar Serat Kasar}

Kadar serat kasar bubur bayi instan dengan substitusi tepung Ip dan Lk berkisar antara 1,69-
5,93\%. Kandungan serat kasar dalam makanan bayi dan balita disyaratkan tidak lebih dari $5 \mathrm{~g}$ per $100 \mathrm{~g}$ makanan. ${ }^{8}$ Hanya Tepung Ip dan Lb (20\% dan 15\%) merupakan satu-satunya formula yang mengandung serat kasar memenuhi persyaratan.

\section{Kandungan Gizi MP ASI Bubur Bayi}

\section{Nilai Energi}

Kandungan energi dalam $100 \mathrm{~g}$ bubur bayi instan dengan substitusi tepung Ip dan Lk berkisar antara 423 Kkal seperti pada tabel 3. Kandungan energi minimal yang disyaratkan dalam spesifikasi adalah $400 \mathrm{kkal} / 100 \mathrm{~g}$ sehingga semua formula ini telah memenuhi syarat Kemenkes. ${ }^{12}$

\section{Kadar Protein}

Kadar protein bubur bayi instan dengan substitusi tepung Ip dan Lk berkisar antara 19,2822,45\%. Dalam spesifikasi MP-ASI bubuk instan untuk bayi usia 6-12 bulan, disyaratkan kandungan protein sebesar $15-22 \mathrm{~g}$ dalam $100 \mathrm{~g}$ MP-ASI. ${ }^{12}$ Rerata kandungan protein dalam bubur bayi instan ketiga formula telah sesuai dengan spesifikasi.

\section{Kadar Betakaroten}

Kadar betakaroten bubur bayi instan dengan substitusi tepung Ip dan Lk berkisar antara 9,22-19,62 $\mathrm{mg} / 100 \mathrm{gr}$. Bubur bayi instan formula tepung Ip dan Lk (20\%dan15\%) mengandung betakaroten tertinggi secara signifikan dibandingkan tiga formula lainnya.

Tabel 2. Hasil Analisis Daya Terima MP-ASI Bubur Bayi Instan

\begin{tabular}{ccccccccr}
\hline \multirow{2}{*}{ Formula } & \multicolumn{2}{c}{ Warna } & \multicolumn{2}{c}{ Aroma } & \multicolumn{2}{c}{ Tekstur } & \multicolumn{2}{c}{ Rasa } \\
\cline { 2 - 9 } & Rerata & Ket & Rerata & Ket & Rerata & Ket & Rerata & Ket \\
\hline A & $5,30 \pm 1,13$ & Agak Suka & $3,65 \pm 1,66$ & Netral & $4,50 \pm 1,67$ & Agak Suka & $3,75 \pm 1,62$ & Netral \\
B & $5,15 \pm 1,23$ & Agak Suka & $3,90 \pm 1,29$ & Netral & $4,80 \pm 1,20$ & Agak Suka & $4,15 \pm 1,50$ & Netral \\
C & $5,10 \pm 1,37$ & Agak Suka & $3,55 \pm 1,47$ & Netral & $4,30 \pm 1,44$ & Netral & $4,10 \pm 1,41$ & Netral \\
D & $5,40 \pm 1,19$ & Agak Suka & $3,40 \pm 1,43$ & Agak Tidak Suka & $4,75 \pm 1,29$ & Agak Suka & $3,80 \pm 1,28$ & Netral \\
\hline
\end{tabular}

Tabel 3. Hasil Analisis Kandungan Zat Gizi Bubur Bayi Instan dengan Substitusi Tepung Ikan Patin dan Tepung Labu Kuning

\begin{tabular}{ccccccccc}
\hline \multirow{2}{*}{ Formula } & \multicolumn{7}{c}{ Rerata Kandungan Zat Gizi } \\
\cline { 2 - 9 } & $\begin{array}{c}\text { Protein } \\
(\%)\end{array}$ & $\begin{array}{c}\text { Betakaroten } \\
(\mathrm{mg} / 100 \mathrm{~g})\end{array}$ & $\begin{array}{c}\text { Lemak } \\
(\%)\end{array}$ & $\begin{array}{c}\text { Air } \\
(\%)\end{array}$ & $\begin{array}{c}\text { Abu } \\
(\%)\end{array}$ & $\begin{array}{c}\text { Serat } \\
\text { Kasar }(\%)\end{array}$ & $\begin{array}{c}\text { Karbohi } \\
\text { drat }(\%)\end{array}$ & $\begin{array}{c}\text { Energi } \\
(\text { Kkal} / 100 \mathrm{~g})\end{array}$ \\
\hline & $19,72 \pm$ & $9,22 \pm$ & $11,34 \pm$ & $5,44 \pm$ & $2,76 \pm$ & $5,18 \pm$ & $60,74 \pm$ \\
A & $0,20^{\mathrm{b}}$ & $0,11^{\mathrm{d}}$ & $0,03^{\mathrm{c}}$ & $0,11^{\mathrm{b}}$ & $0,18^{\mathrm{b}}$ & $0,10^{\mathrm{a}}$ & $0,09^{\mathrm{a}}$ & $423,90 \pm 0,65$ \\
& $19,28 \pm$ & $14,79 \pm$ & $12,02 \pm$ & $5,62 \pm$ & $3,30 \pm$ & $5,93 \pm$ & $59,78 \pm$ & \\
$\mathrm{B}$ & $0,81^{\mathrm{b}}$ & $0,05^{\mathrm{b}}$ & $0,13^{\mathrm{b}}$ & $0,22^{\mathrm{ab}}$ & $0,12^{\mathrm{a}}$ & $0,69^{\mathrm{a}}$ & $0,93^{\mathrm{a}}$ & $424,42 \pm 1,74$
\end{tabular}




\begin{tabular}{ccccccccc} 
& $22,45 \pm$ & $9,69 \pm$ & $14,97 \pm$ & $5,36 \pm$ & $2,87 \pm$ & $5,24 \pm$ & $54,34 \pm$ & \\
$\mathrm{C}$ & $1,20^{\mathrm{a}}$ & $0,05^{\mathrm{c}}$ & $0,15^{\mathrm{a}}$ & $0,05^{\mathrm{b}}$ & $0,08^{\mathrm{b}}$ & $0,12^{\mathrm{a}}$ & $0,97^{\mathrm{b}}$ & $441,89 \pm 0,57$ \\
& $21,47 \pm$ & $19,62 \pm$ & $11,41 \pm$ & $5,81 \pm$ & $2,84 \pm$ & $1,69 \pm$ & $58,48 \pm$ & \\
$\mathrm{D}$ & $0,97^{\mathrm{ab}}$ & $0,21^{\mathrm{a}}$ & $0,40^{\mathrm{c}}$ & $0,03^{\mathrm{a}}$ & $0,11^{\mathrm{b}}$ & $1,24^{\mathrm{b}}$ & $1,43^{\mathrm{a}}$ & $422,49 \pm 1,70$ \\
\hline
\end{tabular}

Keterangan: Angka yang diikuti dengan huruf superscript berbeda (a,b,c, d) menunjukkan beda nyata.

Tabel 4. Sumbangan Kecukupan Gizi per Takaran Saji Bubur Bayi Instan dengan Substitusi Tepung Ikan Patin dan Tepung Labu Kuning

\begin{tabular}{lccc}
\hline & Kandungan per Takaran Saji & AKG & \% AKG \\
\hline Energi (Kkal) & 105 g) & 625 & 16,90 \\
Protein (g) & 5,37 & 16 & 33,56 \\
Vitamin A $(\mu \mathrm{g})$ & 408,75 & 400 & 102,2 \\
\hline
\end{tabular}

Keterangan: Berdasarkan kecukupan energi, protein, dan vitamin A bayi usia 9 bulan dengan BB 8,5 Kg dan TB $71 \mathrm{~cm}^{27}$

\section{Kadar Lemak}

Bubur bayi instan dengan substitusi tepung Ip dan Lk memiliki kadar lemak sebesar 11,34-14,97\%. Keempat formulasi bubur bayi instan yang dihasilkan mengandung lemak dalam rentang yang disyaratkan yaitu $10-15 \mathrm{~g}$ dalam $100 \mathrm{~g}$ MP-ASI. ${ }^{12}$. Bubur bayi instan formula substitusi tepung Ip dan Lk (20\% dan10\%) mengandung lemak tertinggi secara nyata.

\section{Kadar Karbohidrat}

Karbohidrat bagi bayi merupakan sumber energi utama. Asupan karbohidrat setidaknya harus memenuhi $52-54 \%$ kebutuhan energi. Kadar karbohidrat dihitung secara carbohydrate by difference. Perhitungan cara ini sangat dipengaruhi oleh kandungan zat gizi lain seperti air, abu, serat, protein, dan lemak. Bahan-bahan bubur bayi instan yang mengandung karbohidrat tinggi antara lain tepung beras tergelatinisasi, susu skim, tepung labu kuning, dan gula halus. Kadar karbohidrat bubur bayi instan dengan substitusi tepung Ip dan Lk berkisar antara 54,34-60,74\%. Pada bayi kebutuhan karbohidrat sebesar 50-60\% dari total energi.

\section{Kontribusi Energi Bubur Bayi Terhadap Kecukupan Gizi}

Keempat formula bubur bayi instan yang dihasilkan memiliki kandungan protein, lemak, karbohidrat, dan energi yang sesuai dengan spesifikasi. Berdasarkan pertimbangan tersebut, bubur bayi instan yang disarankan untuk dikonsumsi adalah bubur bayi formula substitusi tepung Ip dan $\mathrm{Lk}$ (20\%dan 15\%).

\section{PEMBAHASAN}

\section{Sifat Fisik MP ASI Bubur Bayi Instan}

\section{Densitas Kamba}

Densitas kamba bubur bayi instan dengan substitusi tepung Ip dan Lk berkisar antara 0,46-0,48 $\mathrm{g} / \mathrm{ml}$. Nilai tersebut berada pada rentang densitas kamba bubur komersial, yaitu 0,37-0,50 g/ml. Variasi persentase substitusi tepung ikan patin dan tepung labu kuning tidak berpengaruh pada densitas kamba bubur bayi instan ( $\mathrm{p}=0.287)$.

MP-ASI yang memiliki densitas kamba tinggi menunjukkan bahwa produk tersebut lebih ringkas (non voluminous). Produk pangan yang memiliki densitas kamba tinggi menunjukkan kepadatan gizi yang tinggi pula. ${ }^{8}$ Kapasitas fungsional lambung bayi hanya $30 \mathrm{~g} / \mathrm{Kg}$ berat badan sehingga makanan dengan densitas kamba tinggi diperlukan agar bayi menjadi tidak cepat kenyang dan asupan gizi terpenuhi. ${ }^{20,6}$

\section{Daya Terima}

Warna kuning cerah yang dihasilkan berasal dari substitusi tepung Lk serta penambahan minyak kelapa sawit. Tepung Lk dan minyak kelapa kelapa sawit mengandung betakaroten yang berwarna oranye. Suhu pengeringan untuk membuat tepung labu kuning sebesar $50^{\circ} \mathrm{C}$ sehingga kadar betakaroten masih dapat dipertahankan. ${ }^{5}$ Tepung Ip memiliki aroma yang amis sementara tepung Lb beraroma karamel dan sedikit langu. Pada keempat formula tidak ditambahkan perisa (flavoring) dan sebaiknya ditambahkan perisa untuk menutupi aroma amis. Adapun perisa yang dapat digunakan untuk MP-ASI antara lain vanilin dengan kadar tidak lebih dari $7 \mathrm{~g} / 100 \mathrm{~g}$ bahan siap konsumsi atau ekstrak bahan-bahan alami seperti pandan dan vanilla. ${ }^{4}$

Bubur bayi instan yang dihasilkan memiliki rasa manis dan gurih. Rasa manis berasal dari pemakaian gula bubuk dan tepung labu kuning. Sementara susu skim dan tepung ikan patin memberikan rasa gurih. Penggunaan gula dapat meningkatkan rasa bubur bayi instan, namun pemakaiannya harus dibatasi karena kadar kemanisan yang tinggi dapat menyebabkan bayi mudah kenyang. ${ }^{8}$ 


\section{Sifat Kimia MP ASI Bubur bayi instan}

\section{Kadar Air}

Kadar air bubur bayi instan dengan substitusi tepung Ip dan Lb berkisar antara 5,36-5,81\%. Kadar air pada semua formula masih lebih tinggi dibandingkan persyaratan, yaitu 4 g/100 g MP-ASI. Kadar air bubur bayi instan yang tinggi diduga dipengaruhi oleh metode pengeringan masing-masing bahan (dry mixing) karena tidak adanya proses pemanasan setelah bahan-bahan dicampur. Tepung labu kuning mengandung air sebesar $11,57 \%$. Kadar air tepung $\mathrm{Lk}$ paling tinggi dibandingkan dengan bahan-bahan yang lain sehingga semakin banyak substitusi tepung Lk maka kadar air bubur bayi instan semakin tinggi.

\section{Kadar Abu}

Bubur bayi instan dengan substitusi tepung Ip dan Lk mengandung abu 2,76-3,30\%. Dalam SNI 017111.4-2005, kadar abu disyaratkan tidak lebih dari 3,5 g per 100 gram produk MP-ASI. Semua formula yang dihasilkan masih memenuhi persyaratan tersebut.

Kadar abu suatu bahan pangan mempunyai hubungan dengan kadar mineral yang merupakan zat anorganik. Jumlah mineral dalam tubuh harus dalam batas optimal. Baik kelebihan dan kekurangan mineral dapat mengganggu kesehatan. ${ }^{7,19}$ Oleh karena itu kadar abu dalam MP-ASI perlu dibatasi.

\section{Kadar Serat Kasar}

Kadar serat kasar bubur bayi instan dengan substitusi tepung Ip dan Lk berkisar antara 1,69$5,93 \%$. Kandungan serat kasar dalam makanan bayi dan balita disyaratkan tidak lebih dari $5 \mathrm{~g}$ per $100 \mathrm{~g}$ makanan. ${ }^{8}$ Hanya Tepung Ip dan Lb (20\% dan $\left.15 \%\right)$ merupakan satu-satunya formula yang mengandung serat kasar sesuai persyaratan.

\section{Kandungan Gizi MP ASI Bubur Bayi Nilai Energi}

Kandungan energi minimal yang disyaratkan dalam spesifikasi adalah $400 \mathrm{kkal} / 100 \mathrm{~g}$ sehingga semua formula ini telah memenuhi syarat Kemenkes. ${ }^{12}$ Rerata kebutuhan energi bayi usia 6-8 bulan sebesar $769 \mathrm{Kkal} / \mathrm{hari}$. Apabila bayi tersebut mendapatkan ASI dengan kualitas dan kuantitas sedang, asupan energi sebesar 413 Kkal dapat dipenuhi melalui ASI. Kekurangan 356 Kkal diharapkan dapat dipenuhi melalui MP-ASI. ${ }^{6}$ Oleh karena itu energi minimal yang disyaratkan dalam MP-ASI sebesar $400 \mathrm{kkal} / 100 \mathrm{~g}$.

\section{Kadar Protein}

Dalam spesifikasi MP-ASI bubuk instan untuk bayi usia 6-12 bulan, disyaratkan kandungan protein sebesar 15-22 g dalam 100 g MP-ASI. ${ }^{12}$ Rerata kandungan protein dalam bubur bayi instan ketiga formula telah sesuai dengan spesifikasi. Protein bermutu tinggi dibutuhkan untuk tumbuh kembang bayi. Usia 6-12 bulan merupakan masa kritis karena pertumbuhan yang cepat terjadi dan bayi memerlukan makanan tambahan. ${ }^{15}$ Bahan pangan sumber protein yang digunakan dalam bubur bayi instan adalah tepung ikan patin dan susu skim. Keduanya merupakan protein hewani yang memiliki mutu protein lebih tinggi dibanding protein nabati. Ikan memiliki skor asam amino sebesar 71 sementara skor asam amino susu sapi sebesar 95. ${ }^{18}$ Keduanya telah memenuhi syarat mutu protein MP-ASI yaitu skor asam amino sekurang-kurangnya $65 .{ }^{8}$

\section{Kadar Betakaroten}

Kadar betakaroten dalam bubur bayi instan yang dihasilkan meskipun melebihi spesifikasi setelah dikonversi ke dalam vitamin A, kadarnya berkisar antara 9,22-19,62 mg/100 g atau di bawah $30 \mathrm{mg}$ sehingga tidak akan menimbulkan akumulasi karotenoid. Vitamin A sangat penting untuk penglihatan, pertumbuhan, diferensiasi dan proliferasi sel, reproduksi, serta sistem imun. ${ }^{15}$ Konsumsi vitamin A dosis besar hingga 100 kali jumlah yang dibutuhkan dapat menyebabkan toksisitas. Akan tetapi asupan betakaroten yang tinggi hingga $30 \mathrm{mg}$ per hari tidak menimbulkan efek samping. ${ }^{7}$

\section{Kadar Lemak}

Bubur bayi instan dengan substitusi tepung Ip dan Lk memiliki kadar lemak sebesar 11,34-14,97\%. Keempat formulasi bubur bayi instan yang dihasilkan mengandung lemak dalam rentang yang disyaratkan yaitu $10-15 \mathrm{~g}$ dalam $100 \mathrm{~g}$ MP-ASI. ${ }^{12}$ Bubur bayi instan formula substitusi tepung Ip dan Lk (20\% dan10\%) mengandung lemak tertinggi secara nyata.

\section{Kadar Karbohidrat}

Karbohidrat bagi bayi merupakan sumber energi utama. Asupan karbohidrat setidaknya harus memenuhi 52-54\% kebutuhan energi. Kadar karbohidrat dihitung secara carbohydrate by difference. Perhitungan cara ini sangat dipengaruhi oleh kandungan zat gizi lain seperti air, abu, serat, protein, dan lemak. Bahan-bahan bubur bayi instan yang mengandung karbohidrat tinggi antara lain tepung beras tergelatinisasi, susu skim, tepung labu kuning, dan gula halus. Kadar karbohidrat bubur bayi instan dengan substitusi tepung Ip dan Lk berkisar antara 54,34-60,74\%. Pada bayi kebutuhan karbohidrat sebesar $50-60 \%$ dari total energi. Formula bubur bayi istan dengan substitusi tepung Ip dan Lk sudah memenuhi kebutuhan karbohidrat pada bayi. Tidak ada persyaratan mengenai kisaran 
kandungan karbohidrat dalam spesifikasi MP-ASI, akan tetapi kadar karbohidrat pada bubur bayi instan ini sedikit lebih rendah dibandingkan bubur bayi instan komersial $(66,870,8 \mathrm{~g} / 100 \mathrm{~g})$.

\section{Kontribusi Energi Bubur Bayi Terhadap Kecukupan Gizi}

Keempat formula bubur bayi instan yang dihasilkan memiliki kandungan protein, lemak, karbohidrat, dan energi yang sesuai dengan spesifikasi. Berdasarkan pertimbangan tersebut, bubur bayi instan yang disarankan untuk dikonsumsi adalah bubur bayi formula substitusi tepung Ip dan $\mathrm{Lk}$ (20\%dan 15\%)

Pada tabel 4, penentuan takaran saji bertujuan untuk menentukan besar porsi MP-ASI bubur bayi instan yang dapat memenuhi $1 / 3$ kecukupan protein bayi dalam satu kali konsumsi. ${ }^{2}$ Angka kecukupan protein untuk bayi usia 9 bulan dengan berat badan $8,5 \mathrm{~kg}$ sebesar $16 \mathrm{~g}(1,9 \mathrm{~g} / \mathrm{Kg} \mathrm{BB}) .{ }^{6}$ Berdasarkan perhitungan dengan menggunakan acuan formula substitusi tepung Ip dan Lk (20\%dan 15\%) maka diperoleh takaran saji sebesar $25 \mathrm{~g}$. Berdasarkan penelitian WHO, pemberian ASI yang cukup pada bayi usia 6-12 bulan menyumbang energi sebesar 413 Kkal kemudian dipenuhi dengan pemberian ASI dan konsumsi dua takaran saji bubur bayi instan

\section{SIMPULAN}

Formula bubur bayi instan dengan substitusi tepung ikan patin dan tepung labu kuning paling tepat kandungan zat gizi dan sesuai spesifikasi MP-ASI adalah formula D. Densitas kamba MP-ASI bubur bayi instan dengan substitusi tepung ikan patin dan tepung labu kuning sesuai dengan rentang densitas kamba bubur bayi komersial.

Warna, aroma, tekstur, dan rasa MP-ASI bubur bayi instan dengan substitusi tepung ikan patin dan tepung labu kuning dapat diterima oleh panelis dewasa. Konsumsi satu takaran saji bubur bayi instan formula D sebesar $25 \mathrm{~g}$ dapat memberikan kontribusi $33,56 \%$ kecukupan protein dan 102,2\% kecukupan vitamin A bayi usia 9 bulan dengan berat badan 8,5 $\mathrm{Kg}$.

\section{DAFTAR PUSTAKA}

1. Amirullah, TC. Fortifikasi Tepung Ikan Tenggiri (Scomberomorus Sp.) dan Tepung Ikan Swangi (Priacanthus Tayenus) dalam Pembuatan Bubur Bayi Instan [Skripsi]. Bogor: Institut Pertanian Bogor. 2008.

2. Andarwulan N, Fatmawati S. Formulasi Bubur Bayi Berprotein Tinggi dan Kaya Antioksidan dari Tepung Kecambah Kacang Tunggak (Vigna unguilucata) untuk Makanan Pendamping ASI Prosiding Seminar Nasional dan Kongres Perhimpunan Ahli Teknologi Pangan Indonesia. 2004

3. Astari LD, Nasoetion A, Dwiriani CM. Hubungan Konsumsi ASI dan MP-ASI Serta Kejadian Stunting Anak Usia 6-12 Bulan di Kabupaten Bogor. Media Gizi dan Keluarga, 2006, 30 (1): 15-23

4. Badan Standardisasi Nasional. SNI01-7111.42005 Makanan Pendamping Air Susu Ibu (MP-ASI) Bagian 4: Siap Santap [Serial Online]. 2005. [Dikutip 12 Februari 2011]. Available from http://websisni.bsn.go.id/ index.php?/sni_main/sni/detail_sni/7105

5. Britton G, Liaaen-Jensen $\mathrm{S}$, Pfander $\mathrm{H}$. Carotenoids Volume 5: Nutrition and Health. Switzerland: Birkhäuser Verlag. 2009.

6. Dewey KG, Brown KH. Update on Technical Issues Concerning Complementary Feeding of Young Children in Developing Countries and Implications for Intervention Programs. Food and Nutrition Bulletin, vol. 24, no. 1. The United Nations University. 2003

7. Gallagher ML. The Nutrients and Their Metabolism. In: Mahan LK, EscottStump. S. Krause's Food and Nutrition Theraphy $12^{\text {th }}$ ed. Canada: Elsevier. 2008

8. Hadiningsih N. Optimasi Formula Makanan Pendamping ASI dengan Menggunakan Response Surface Methodology [Tesis]. Sekolah Pascasarjana Institut Pertanian Bogor. 2004

9. Hendrasty HK. Tepung Labu Kuning: Pembuatan dan Pemanfaatannya. Yogyakarta: Kanisius; 2003.

10. Khairuman, Sudenda D. Budidaya Patin Secara Intensif. Jakarta: Agromedia Pustaka. 2009

11. Kusumawardani B. Hubungan Praktik Higiene Sanitasi Makanan Pendamping Air Susu Ibu (MPASI) Tradisional Dengan Kejadian Diare Pada Anak Usia 6-24 Bulan Di Kota Semarang [Skripsi]. Universitas Diponegoro. 2010

12. Kementerian Kesehatan Republik Indonesia. Keputusan Menteri Kesehatan Republik Indonesia Nomor: 224/Menkes/SK/II/2007 Tentang Spesifikasi Teknis Makanan Pendamping Air Susu Ibu (MP-ASI). Jakarta. 2007.

13. Moeljanto. Pengawetan dan Pengolahan Hasil Perikanan. Jakarta: Penebar Swadaya. 1994

14. Mien K. Mahmud, Hermana, Nils Aria Z, Rossi Rozanna A, Iskari Ngadiarti, Budi Hartati. Tabel Komposisi Pangan Indonesia (TKPI). Jakarta: PT Elex Media Komputindo. 2009. 
15. Parízková J. Nutrition, Physical Activity, and Health in Early Life $2^{\text {nd }}$ edition. USA: CRC Press. 2010

16. Trahms CM, McKean KN. Nutrition During Infancy. In: Mahan LK, Escott-Stump S. Krause's Food and Nutrition Theraphy $12^{\text {th }}$ ed. Canada: Elsevier. 2008

17. World Health Organization. Complementary Feeding: Family Foods for Breastfed Children.
Department of Nutrition and Development. Geneva: WHO. 2000

18. Whitney EN, Rolfes SR. Understanding Nutrition. USA: Wadsworth Publishing. 2004

19. Winarno. Kimia Pangan dan Gizi. Jakarta: PT Gramedia Pustaka Utama; 2002

20. Yoanasari QT. Pembuatan Bubur Bayi Instan dari Pati Garut [skripsi]. Bogor: Institut Pertanian Bogor.2003. 